Received 12.07.2017 Reviewed 15.10.2017 Accepted 14.11.2017

A - study design

B - data collection

C - statistical analysis

D - data interpretation

E - manuscript preparation

F - literature search

\section{Evaluation of infiltration models} for mineral soils with different land uses in the tropics

\author{
Nugroho SURYOPUTRO ${ }^{\text {1) ABCDEF, }}$ \\ SUHARDJONO ${ }^{2)}$ AD , Widandi SOETOPO ${ }^{2)}$ CD, \\ Ery S. SUHARTANTO ${ }^{2)}$ DF , Lily M. LIMANTARA ${ }^{2) ~ D E ~} \bowtie$
}

1) State University of Malang, Faculty of Engineering, Department of Civil Engineering, Malang, East Java Province, Indonesia; e-mail: nugrohosuryoputro@gmail.com

${ }^{2)}$ University of Brawijaya, Faculty of Engineering, Department of Water Resources, Jl. Mt Haryono No 167, 65141 Malang, East Java Province, Indonesia; e-mail: suhardjonosisno@yahoo.co.id; widandi@ub.ac.id; erysuhartanto@yahoo.com; lilymont2001@gmail.com

For citation: Suryoputro N., Suhardjono, Soetopo W., Suhartanto E.S., Limantara L.M. 2018. Evaluation of infiltration models for mineral soils with different land uses in the tropics. Journal of Water and Land Development. No. 37 p. 153-160. DOI: $10.2478 /$ jwld-2018-0034.

\begin{abstract}
The aims of this study were to evaluate five infiltration models for mineral soils in the tropics with different land use types, such as settlements, plantations, rice fields, and forests. The infiltration models evaluated were Green-Ampt, Kostiakov, Kostiakov-Lewis, Philip, and Horton. The research was conducted at the Amprong watershed, Malang, Indonesia. The infiltration rate of the thirteen soil samples was analysed. The infiltration was tested using Turf-Tech infiltrometer. Moreover, each soil sample was tested in terms of the bulk density, specific gravity, porosity, soil moisture, and soil texture. The results of the study indicate that there is no significant difference $(\alpha=5 \%)$ in the infiltration rate among the five models of infiltration. The infiltration rate in the study site was considered fast. Three models exhibiting the best performance are Kostiakov, Kostiakov-Lewis, and Horton model, respectively. The highest infiltration rate occurred in the forest land use while the lowest occurred in the rice field land use. The results of this study suggest that the infiltration model parameters correlate closely with the initial infiltration rate $(f o)$ and the final infiltration rate $(f c)$. In other words there is a correlation between the soil's ability to absorb water (representing the capillary force or horizontal flow) at the beginning of the infiltration $\left(f_{o}\right)$ and the gravity or the vertical flow upon reaching the final infiltration rate $(f c)$.
\end{abstract}

Key words: infiltration models, land use, mineral soil, tropical climate

\section{INTRODUCTION}

Land use affects the rate of erosion, the level of soil moisture, the availability of soil nutrients, the return of biomass to the soil, interception, and the soil structure [PRIJONO et al. 2015]. Changes in land use can reduce the soil quality and increase the soil degradation [AGHASI et al. 2010], causing a devastating impact on the physical and chemical characteristics, fertility and erodibility of soil. The results of several studies suggested that changes in land use in tropical ecosystems result in changes in soil characteristics. The most rapid change occurs in the chemical and biological characteristics of the soil [SCHIPPER, SPARLING 2000]. The changes in land use also influence the amount of runoff [LI et al. 2009].

Infiltration is the process by which water (generally derived from rainfall) flows into the soil as a result of capillary force (water movement in the vertical direction). Once the topsoil is saturated, the excess of 
water flows deeper into the ground as a result of the gravity; this process is known as the percolation process [ASDAK 2002].

The infiltration rate is influenced by a number of factors such as the physical characteristics of the soil, rainfall, vegetation cover, initial soil moisture, and fertilization [CZYŻYK, ŚWIERKOT 2017; ORUK 2011]. The physical characteristics of soil are affected by the soil textures which consist of mineral particles including sand, silt, and clay [HAGHNAZARI et al. 2015]. Another factor influencing the infiltration is land use [THORNLEYA, CANNELL 2010].

According to Indonesian Centre for Agricultural Land Resources Research and Development (Ind. Balai Besar Litbang Sumberdaya Lahan Pertanian Indonesia), the soil in Indonesia, in terms of its parent material, is divided into two major groups, namely organic soil (peat soil) and mineral soil [SUBARDJA et al. 2014]. Mineral soil is made up of horizons consisting of 20 to $35 \%$ organic matter, or in other words, the horizons of mineral soil are approximately 65 to $80 \%$ [USDA, NRCS 2010]. The fact that Indonesia's land area lies across the equator provides benefits in terms of the tropical wet climate and the high temperature which can accelerate the process of weathering of rocks and provide a high biodiversity. In addition, the high diversity of soil parent materials provides a wide variety of nature and types of soil formed. Each type of soil has its own distinctive characteristics and properties [SUBARDJA et al. 2014]

This study aimed at evaluating five infiltration models for mineral soils in the tropics with different land uses.

\section{RESEARCH MATERIALS AND METHODS}

\section{RESEARCH MATERIALS AND SETTING}

The research was conducted in a $349 \mathrm{~km}^{2}$ watershed in Amprong, Malang. The measurements were carried out in January to March 2017. The soil samples were analysed in Soil Physics Laboratory, Department of Soil Science, Faculty of Agriculture, Uni- versity of Brawijaya. The type of tests, method, and the equipment used in this research are listed in Table 1.

The research materials were a map of the research setting and soil samples. The apparatus used consisted of a soil-sampling ring kit, and a turf-tech for measuring infiltration rate [FULAZZAKY et al. 2014]. The infiltration measurement was for one hour.

The rainfall data from 2000-2014 were obtained from National Agency of Water Resources Development (UPT PSAWS) of Bango-Gedangan, Malang, while the data on temperature, evaporation, relative humidity, and wind speed from 2005 to 2015 were obtained from the Agency for Meteorology, Climatology and Geophysics or BMKG located in Karangploso, Malang.

Five types of minerals soils samples were collected from different land uses i.e. settlements, plantations, rice fields, and forests (Tab. 2). According to the Roscoe method [ROSCOE 1975], a sample size of over 30 and less than 500 samples are appropriate for most studies. Due to the research schedule and the cost estimation consideration, the sampling has only collected in 39 locations with triplicates. It was reported by LEMESHOW et al. [1990] that the number of 39 sample with 95\% confidence level will produce a margin error at approximately $\pm 16 \%$.

The research setting was located at an elevation between $+500 \mathrm{~m}$ and $+1500 \mathrm{~m}$ a.s.l. with the coordinates of longitude $112.65-112.94^{\circ}$ East and latitude 7.89-8.06 South.

The data in this quantitative descriptive study were collected through the field survey. The soil sampling locations were selected by using simple stratified random sampling based on the type of mineral soil (5 types of mineral soils).

\section{MODEL DESCRIPTION}

The five infiltration models evaluated in this study were the Green-Ampt, Kostiakov, KostiakovLewis, Philip, and Horton model.

\section{1) The Green-Ampt model}

GREEN and AMPT [1911] developed a physical theory that can be solved with an exact analytical so-

Table 1. The list of instruments used in the research

\begin{tabular}{|c|c|c|}
\hline Test types & Method & Equipment \\
\hline Bulk density $\left(\rho_{\text {bulk }}\right)$ & undisturbed soil (sample ring) & $\begin{array}{l}\text { 3-inch diameter ring with depth of } 3 \text { inches, analytical balance } \\
\text { ( } 0.1 \text { g precision }) \text {, microwave oven }\end{array}$ \\
\hline Particle density $\left(\rho_{\text {particle }}\right)$ & undisturbed soil (sample ring) & $\begin{array}{l}\text { scale }(0.1 \mathrm{~g} \text { precision }) \text {, microwave oven, volumetric flask } \\
\left(100 \mathrm{~cm}^{3}\right) \text {, graduated cylinder }\left(0.1 \mathrm{~cm}^{3} \text { scale }\right)\end{array}$ \\
\hline Porosity $(\phi)$ & $\phi=1-\frac{\rho_{\text {bulk }}}{\rho_{\text {particle }}}$ & - \\
\hline Soil moisture & gravimetric & similar equipment of bulk density test was used \\
\hline Soil texture & $\begin{array}{l}\text { pipette method, grain sieve analy- } \\
\text { sis, chart of USDA soil texture }\end{array}$ & $\begin{array}{l}500 \mathrm{~cm}^{3} \text { Erlenmeyer flask, } 10 \mathrm{~cm}^{3}, 50 \mathrm{~cm}^{3} \text {, and } 1.000 \mathrm{~cm}^{3} \text { graduated } \\
\text { cylinder, beaker glass, } 0.05 \mathrm{~mm} \text { sieve, mechanical sieve shaker, pi- } \\
\text { pette, analytical balance }(0.1 \mathrm{~g} \text { precision }) \text {, stirrer, microwave oven }\end{array}$ \\
\hline Organic matter & Walkley-Black method & Erlenmeyer flask, $10 \mathrm{~cm}^{3} \mathrm{~K}_{2} \mathrm{Cr}_{2} \mathrm{O}_{7} 1 \mathrm{~N}, 20 \mathrm{~cm}^{3} \mathrm{H}_{2} \mathrm{SO}_{4}$, aquades \\
\hline Statistical tests and programs & $\begin{array}{l}\text { mean, standard deviation, graph, } \\
R M S E, N S E, r^{2}\end{array}$ & spreadsheet software \\
\hline
\end{tabular}

Explanations: $R M S E=$ root mean square error, $N S E=$ Nash-Sutcliffe efficiency coefficient, $r^{2}=$ determination coefficient.

Source: Soil Physics Laboratory, Faculty of Agriculture, University of Brawijaya. 
Table 2. Types of mineral soil and land use in Amprong watershed

\begin{tabular}{|c|c|c|c|c|}
\hline No & Type of mineral soil & Land use & Code & $\begin{array}{c}\text { Number } \\
\text { of samples }\end{array}$ \\
\hline \multirow{4}{*}{1} & \multirow{4}{*}{ dark-grey alluvium } & settlements & AP1-PMK & 3 \\
\hline & & plantation & AP1-KBN & 3 \\
\hline & & rice field & AP1-SWH & 3 \\
\hline & & forest & - & - \\
\hline \multirow{4}{*}{2} & \multirow{4}{*}{$\begin{array}{l}\text { association of reddish } \\
\text { brown latosol and } \\
\text { brown latosol }\end{array}$} & settlements & AP2-PMK & 3 \\
\hline & & plantation & AP2-KBN & 3 \\
\hline & & rice field & - & - \\
\hline & & forest & - & - \\
\hline \multirow{4}{*}{3} & \multirow{4}{*}{ brown regosol } & settlements & AP3-PMK & 3 \\
\hline & & plantation & AP3-KBN & 3 \\
\hline & & rice field & AP3-SWH & 3 \\
\hline & & forest & - & - \\
\hline \multirow{4}{*}{4} & \multirow{4}{*}{ reddish brown latosol } & settlements & AP4-PMK & 3 \\
\hline & & plantation & AP4-KBN & 3 \\
\hline & & rice field & - & - \\
\hline & & forest & - & - \\
\hline \multirow{4}{*}{5} & \multirow{4}{*}{$\begin{array}{l}\text { association of brown } \\
\text { andosol and brown } \\
\text { regosol }\end{array}$} & settlements & AP5-PMK & 3 \\
\hline & & plantation & AP5-KBN & 3 \\
\hline & & rice field & - & - \\
\hline & & forest & AP5-HTN & 3 \\
\hline
\end{tabular}

Explanations: the code shows consecutively the name of the watershed, the type of mineral soil, and the land use. Example: AP1PMK; AP = amprong watershed, number $1=$ first mineral soil type (dark gray alluvium), PMK = settlements; “-”: the type of land use is not available.

Source: own study.

lution to determine infiltration [BRAKENSIEK, ONSTAD 2000]. The Green-Ampt model can be expressed as [VAGHEFI, RAHIDEH 2011]:

$$
\begin{gathered}
f(t)=K\left(\frac{\psi \Delta \theta}{F(t)}+1\right) \\
F(t)=K t+\psi \Delta \theta \ln \left(1+\frac{F(t)}{\psi \Delta \theta}\right) \\
\Delta \theta=\eta-\theta i
\end{gathered}
$$

Where: $f(t)=$ the infiltration rate $\left(\mathrm{mm} \cdot \mathrm{min}^{-1}\right) ; F(t)=$ the cumulative infiltration $(\mathrm{mm}) ; K=$ the hydraulic conductivity $\left(\mathrm{mm} \cdot \mathrm{min}^{-1}\right) ; \eta=$ the degree of porosity, $\theta i=$ the initial moisture content, $\psi=$ the suction head (mm), $t=$ the time ( $\mathrm{min})$.

The values of $K$ and $\psi \Delta \theta$ were obtained from observational data.

\section{2) Kostiakov model}

KOSTIAKOV [1932] proposed the following empirical infiltration equation [SUBRAMANYA 2013]:

$$
f(t)=a b t^{b-1}
$$

Where: $f(t)=$ the infiltration rate $\left(\mathrm{mm} \cdot \mathrm{min}^{-1}\right) ; t=$ the time (min), $a$ and $b=$ the empirical parameters $(a>0$ and $0<b<1)$.

\section{3) Kostiakov-Lewis model}

Kostiakov empirical equation has a limitation i.e. the longer the time. The lower the infiltration rate (nearly zero). This contradicts the fact that the infiltration rate will reach a constant value on a much longer time scale. To fix this drawback, the Kostiakov equa- tion was modified into the Kostiakov-Lewis model [WALKER, SKOGERBOE 1987]:

$$
f(t)=a b t^{(b-1)}+f c
$$

Where: $f_{c}=$ the final infiltration rate $\left(\mathrm{mm} \cdot \mathrm{min}^{-1}\right), t=$ the time (min).

\section{4) Philip model}

Philip model [PHILIP 1957] was developed from the RICHARD [1931] equation, with the assumption that the soil moisture profile will approach a constant state and move downward at a constant speed after a long time [HADISUSANTO 2011]. The form of Philip equation is:

$$
f(t)=0.5 S t^{-0.5}+A
$$

Where: $f(t)=$ the infiltration rate $\left(\mathrm{mm} \cdot \mathrm{min}^{-1}\right) ; S=$ the sorptivity which is soil suction potential $\left(\mathrm{mm} \cdot \mathrm{min}^{-0.5}\right)$, $A=$ the saturated hydraulic conductivity $\left(\mathrm{mm} \cdot \mathrm{min}^{-1}\right)$.

\section{5) Horton model}

HORTON's [1940] observation about infiltration showed that the infiltration begins at an initial rate (fo) and decreases exponentially until it reaches a constant value $(f c)$. Horton proposed an empirical equation for a condition where the rainfall intensity is greater than the infiltration rate $f(t)$ [ABDULKADIR et al. 2011]:

$$
f(t)=f c+(f o-f c)^{-\alpha t}
$$

Where: $f(t)=$ the infiltration rate at time $t\left(\mathrm{~mm} \cdot \mathrm{min}^{-1}\right)$, $f_{o}=$ the initial infiltration rate $\left(\mathrm{mm} \cdot \mathrm{min}^{-1}\right), f_{c}=$ the final infiltration rate $\left(\mathrm{mm} \cdot \mathrm{min}^{-1}\right), \alpha=$ a constant of the infiltration rate $\left(\mathrm{min}^{-1}\right)$ which depends on the characteristics of the soil and plant cover.

\section{EVALUATION OF MODEL PERFORMANCE}

The model performance in this study was evaluated based on the following efficiency criteria [KRAUSE et al. 2005]:

\section{1) The coefficient of determination (denoted by $\boldsymbol{r}^{2}$ )}

The coefficient of determination $\left(r^{2}\right)$ is formulated as follows:

$$
r^{2}=\left(\frac{\sum_{i=1}^{n}\left(O_{i}-\bar{O}\right)\left(P_{i}-\bar{P}\right)}{\sqrt{\sum_{i=1}^{n}\left(O_{i}-\bar{O}\right)^{2}} \sqrt{\sum_{i=1}^{n}\left(P_{i}-\bar{P}\right)^{2}}}\right)^{2}
$$

Where: $n=$ the number of observation data during the period under review, $O_{i}=$ the observed value of the $i^{\text {th }}$ model, $\bar{O}=$ the average observed value, $P_{i}=$ the output value of the $i^{\text {th }}$ model, $\bar{P}=$ the average output value.

\section{2) Nash-Sutcliffe efficiency coefficient (NSE)}

NSE coefficient, originally proposed by NASH and SUTCLIFFE [1970], is formulated as follows:

$$
N S E=1-\frac{\sum_{i=1}^{n}\left(O_{i}-P_{i}\right)^{2}}{\sum_{i=1}^{n}\left(O_{i}-\bar{O}\right)^{2}}
$$
and $-\infty$.

The range of NSE lies between 1.0 (perfect fit) 
3) Root mean square error ( $R M S E)$

$R M S E$ is expressed as follows:

$$
R M S E=\sqrt{\frac{\sum_{i=1}^{n}\left(P_{i}-O_{i}\right)^{2}}{n}}
$$

$R M S E$ value $=0$ indicates a very satisfactory model performance.

The statistical criteria for assessing the model performance are summarised in Table 3 [SILVA et al. 2015].

Table 3. The criteria for assessing the performance of hydrological models

\begin{tabular}{|c|c|c|}
\hline Statistical criterion & Value & Classification \\
\hline \multirow{2}{*}{$\begin{array}{l}\text { Coefficient of de- } \\
\text { termination }\left(r^{2}\right)\end{array}$} & $0.00 \leq r^{2} \leq 0.50$ & unsatisfactory \\
\hline & $0.50<r^{2} \leq 1.00$ & satisfactory \\
\hline \multirow{5}{*}{$\begin{array}{l}\text { Nash-Sutcliffe } \\
\text { efficiency coeffi- } \\
\text { cient }(N S E)\end{array}$} & $0.75<N S E \leq 1.00$ & very good \\
\hline & $0.65<N S E \leq 0.75$ & good \\
\hline & $0.50<N S E \leq 0.65$ & satisfactory \\
\hline & $0.40<N S E \leq 0.50$ & acceptable \\
\hline & $N S E \leq 0.40$ & unsatisfactory \\
\hline $\begin{array}{l}\text { Root mean square } \\
\text { error }(R M S E)\end{array}$ & $\begin{array}{l}\text { values below half stand- } \\
\text { ard deviation of the ob- } \\
\text { served data }\end{array}$ & satisfactory \\
\hline
\end{tabular}

Source: own elaboration based on SILVA et al. [2015]

\section{RESULTS AND DISCUSSION}

\section{CLIMATOLOGY}

The average annual precipitation in the study site varies between 1,000 and 1,300 $\mathrm{mm} \cdot$ year $^{-1}$. Due to the influence monsoon, the rainy season occurs from November to March, while the dry season occurs from April to October. The type of climate of the study site, according to the Schmidt-Ferguson classification, is included in the C/D category which means a semi-humid area, while based on the Oldeman method, it belongs to the type C3 which is a wet area (5-6 months) [BMKG 2016]. Judging from KoppenGeiger climate classification, the climate of the study site is categorised into Aw group i.e. a tropical climate area with longer dry season [PEEL et al. 2007].

\section{CHARACTERISTICS OF SOIL}

The results of the infiltration tests in the field and the soil characteristics testing in the soil physics laboratory are presented in Table 4 and Figure 1. Figure 1 shows the coefficient determination $\left(r^{2}\right)$ of the relationship between soil properties and infiltration rate. The figure revealed that the infiltration rate of the soil was influenced by several soil properties: 54 , $83 \%$ of bulk density, $46.57 \%$ of porosity, and $24.58 \%$ of soil moisture. Whereas the remaining percentage from each soil properties of $45.17 \%, 53.43 \%$, and $76,42 \%$ respectively from bulk density, porosity, and soil moisture were not considered in this study due to they were influenced by the other variables.

Texture. In general, the texture of mineral soils at the study site was dominated by silt fraction (51\%), sand $(32.23 \%)$, and clay $(16.77 \%)$.

Bulk density. HARDJOWIGENO [2002] stated that the bulk density indicates the degree of soil compaction. The higher the bulk density, the more solid the soil, which means the more difficult the movement of water into the soil. The soil in the settlements had the highest average bulk density of $1.26 \mathrm{~g} \cdot \mathrm{cm}^{-3}$, while the average bulk density in the plantation was $1.13 \mathrm{~g} \cdot \mathrm{cm}^{-3}$, in the forest was $1.03 \mathrm{~g} \cdot \mathrm{cm}^{-3}$, and in the rice field was $1.02 \mathrm{~g} \cdot \mathrm{cm}^{-3}$.

Porosity and soil moisture. Soil porosity is associated with the ability of soil to absorb water. The soil porosity is also closely related to the bulk density. The more solid the soil, the more difficult the movement of water into the soil. and thus the smaller the soil porosity. The level of soil moisture content (the degree of saturation) affects the rate of infiltration; the more saturated the soil, the lower the infiltration rate [HAGHNAZARI et al. 2015]. The results of porosity analysis showed that the soil in the rice field had the highest porosity value of $56.03 \%$, while the porosity

Table 4. Soil characteristics

\begin{tabular}{|c|c|c|c|c|c|c|c|c|}
\hline \multirow{3}{*}{ Code } & & Textur & & \multirow{3}{*}{ Texture class } & \multirow{3}{*}{$\begin{array}{c}\text { Bulk } \\
\text { density } \\
\mathrm{g} \cdot \mathrm{cm}^{-3} \\
\end{array}$} & \multirow{3}{*}{$\begin{array}{c}\text { Porosity } \\
\% \\
\end{array}$} & \multirow{3}{*}{$\begin{array}{c}\text { Actual soil } \\
\text { moisture } \\
\mathrm{cm}^{3} \cdot \mathrm{cm}^{-3}\end{array}$} & \multirow{3}{*}{$\begin{array}{c}\text { Organic } \\
\text { matter } \\
\% \\
\end{array}$} \\
\hline & sand & silt & clay & & & & & \\
\hline & \multicolumn{3}{|c|}{$\%$} & & & & & \\
\hline AP1-PMK & 21 & 61 & 18 & silt loam & 1.31 & 44.95 & 0.49 & 1.54 \\
\hline AP1-KBN & 66 & 25 & 9 & \begin{tabular}{|l|} 
sandy loam \\
\end{tabular} & 1.39 & 42.50 & 0.47 & 7.51 \\
\hline AP1-SWH & 37 & 46 & 17 & clay & 0.92 & 59.73 & 0.91 & 2.34 \\
\hline AP2-PMK & 22 & 59 & 19 & silt loam & 1.04 & 54.90 & 0.49 & 1.40 \\
\hline AP2-KBN & 10 & 66 & 24 & silt loam & 0.82 & 66.12 & 0.36 & 6.32 \\
\hline AP3-PMK & 31 & 60 & 9 & silt loam & 1.35 & 43.37 & 0.49 & 1.33 \\
\hline AP3-KBN & 31 & 45 & 24 & loam & 1.31 & 48.92 & 0.56 & 6.50 \\
\hline AP3-SWH & 7 & 51 & 42 & silty clay & 1.12 & 52.32 & 0.49 & 1.98 \\
\hline AP4-PMK & 36 & 53 & 11 & silt loam & 1.27 & 44.43 & 0.52 & 1.20 \\
\hline AP4-KBN & 38 & 47 & 15 & loam & 1.21 & 43.39 & 0.59 & 7.03 \\
\hline AP5-PMK & 60 & 37 & 3 & sandy loam & 1.31 & 43.64 & 0.44 & 1.10 \\
\hline AP5-KBN & 26 & 61 & 13 & silt loam & 0.90 & 58.64 & 0.50 & 6.80 \\
\hline AP5-HTN & 34 & 52 & 14 & sandy loam & 1.03 & 53.14 & 0.50 & 9.01 \\
\hline Mean & 32.23 & 51.00 & 16.77 & - & 1.15 & 50.47 & 0.52 & 4.16 \\
\hline Standard deviation & 16.80 & 11.27 & 9.64 & - & 0.19 & 7.68 & 0.13 & 3.01 \\
\hline
\end{tabular}

Explanation: the codes as in Table 2. Source: own study. 

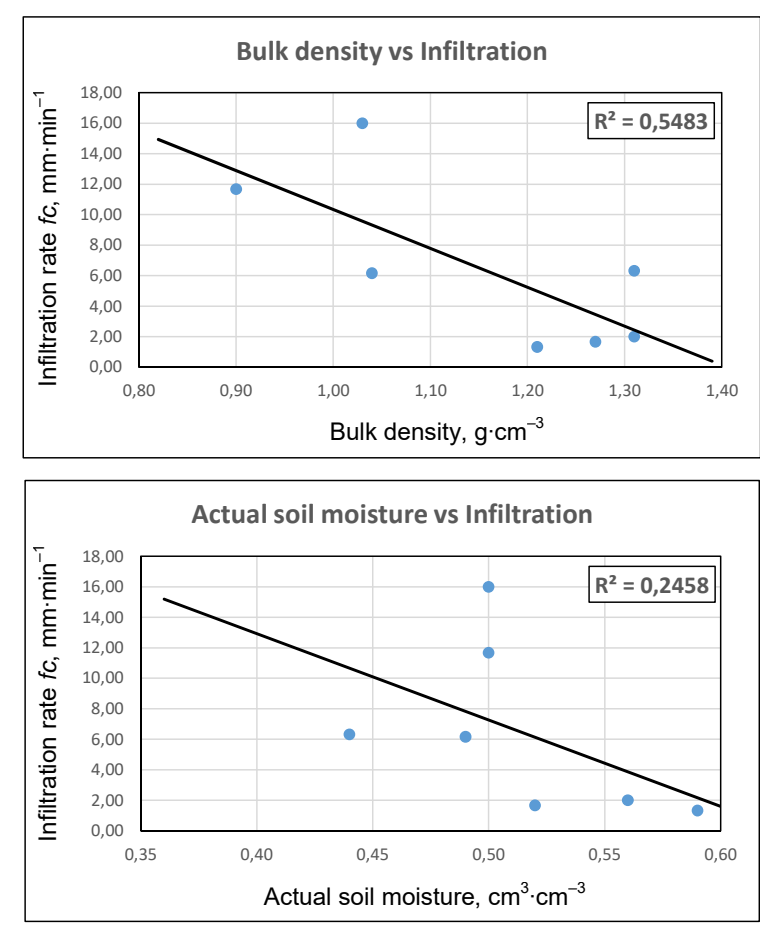

level of soil in the forest was $53.14 \%$, in the plantation was $51.91 \%$, and in the settlements was $46.26 \%$. The greater the porosity, the greater the hydraulic conductivity and the smaller the bulk density; this is in line with DEC et al. [2008].

Regarding the soil moisture content (the degree of saturation), the soil in the rice field had the highest degree of saturation of $0.70 \mathrm{~cm}^{3} \cdot \mathrm{cm}^{-3}$, while the degree of saturation of soil in the forest and plantation is $0.50 \mathrm{~cm}^{3} \cdot \mathrm{cm}^{-3}$, and in the settlements was 0.49 $\mathrm{cm}^{3} \cdot \mathrm{cm}^{-3}$.

\section{INFILTRATION MODEL PARAMETERS}

The parameters of the infiltration models are presented in Table 5 and Table 6.

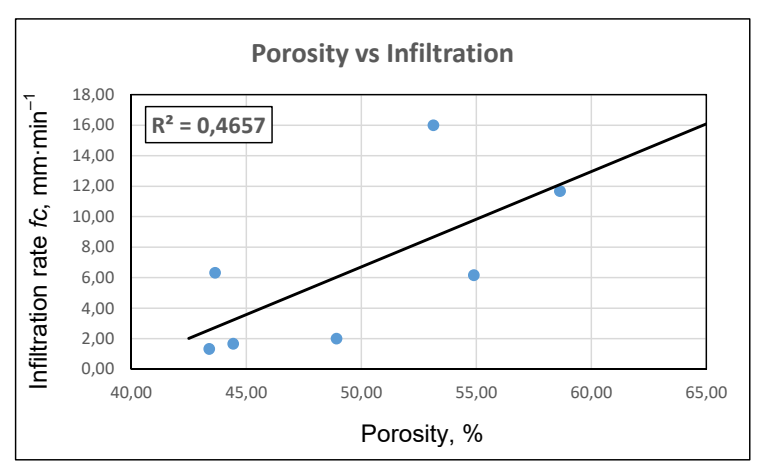

Fig. 1. The relationship between soil properties and final infiltration $(f c)$; source: own study

Table 5 shows the correlation between the model parameters and the infiltration rate. In the GreenAmpt model, the parameters of unsaturated soil $(\Delta \theta)$ and suction head $(\psi)$ are directly proportional to the infiltration rate. In other words, the more unsaturated the soil and the higher the suction head, the higher the infiltration rate. The hydraulic conductivity $(K)$ approaches the final infiltration rate $\left(f_{c}\right)$ at a constant state, which means the gravity plays a more dominant role than the capillary force as the infiltration rate increases. Sandy loam soil had the highest $K$ value; this is in accordance with BRESLER et al. [1984] stating that $24-35 \%$ of the variability of hydraulic conductivity could be connected with the content of the sand. The parameter values of $\Delta \theta$ and $\psi$ correlate fairly well with the ones suggested by RAWLS et al. [1983], while

Table 5. Parameters of Green-Ampt and Kostiakov model

\begin{tabular}{|c|c|c|c|c|c|c|c|}
\hline \multirow{2}{*}{ Code } & $f o$ observ & \multicolumn{2}{|c|}{$f_{\mathcal{c}}$ observ } & \multicolumn{2}{c|}{ Green-Ampt } & \multicolumn{2}{c|}{ Kostiakov } \\
\cline { 2 - 8 } & \multicolumn{2}{|c|}{$\mathrm{mm} \cdot \mathrm{min}^{-1}$} & $\Delta \theta$ & $\psi, \mathrm{mm}$ & $K, \mathrm{~mm} \cdot \mathrm{min}^{-1}$ & $a$ & $b$ \\
\hline AP1-PMK & 2.17 & 0.33 & 0.40 & 953.90 & 0.04 & 1.79 & 0.47 \\
\hline AP1-KBN & 15.00 & 8.00 & 0.38 & 213.52 & 7.16 & 17.43 & 0.20 \\
\hline AP1-SWH & 0.67 & 0.07 & 0.37 & 593.80 & 0.001 & 0.56 & 0.61 \\
\hline AP2-PMK & 6.17 & 1.50 & 0.29 & 681.07 & 0.94 & 5.55 & 0.35 \\
\hline AP2-KBN & 0.33 & 0.17 & 0.28 & 29.20 & 0.17 & 0.64 & 0.31 \\
\hline AP3-PMK & 9.33 & 5.33 & 0.28 & 144.53 & 5.24 & 9.63 & 0.14 \\
\hline AP3-KBN & 2.00 & 0.67 & 0.24 & 124.02 & 0.55 & 2.28 & 0.31 \\
\hline AP3-SWH & 4.00 & 0.67 & 0.27 & 1068.50 & 0.30 & 8.24 & 0.61 \\
\hline AP4-PMK & 1.67 & 0.67 & 0.28 & 88.64 & 0.46 & 2.13 & 0.31 \\
\hline AP4-KBN & 1.33 & 0.33 & 0.23 & 256.08 & 0.16 & 1.53 & 0.41 \\
\hline AP5-PMK & 6.33 & 2.33 & 0.26 & 310.91 & 1.89 & 6.36 & 0.26 \\
\hline AP5-KBN & 11.67 & 5.00 & 0.32 & 263.34 & 4.81 & 12.49 & 0.22 \\
\hline AP5-HTN & 16.00 & 5.00 & 0.38 & 215.47 & 5.49 & 17.17 & 0.27 \\
\hline
\end{tabular}

Explanation: the codes as in Table 2 ; $f o$ observ $=$ observed initial infiltration rate $\left(\mathrm{mm} \cdot \mathrm{min}^{-1}\right), f c$ observ $=$ observed final infiltration rate $\left(\mathrm{mm} \cdot \mathrm{min}^{-1}\right), \Delta \theta=\eta-\theta i, \eta=$ the degree of porosity, $\theta i=$ the initial moisture content, $\psi=$ the suction head $(\mathrm{mm}), K=$ the hydraulic conductivity $\left(\mathrm{mm} \cdot \mathrm{min}^{-1}\right), a, b=$ the empirical parameters.

Source: own study. 
Table 6. Parameters of Kostiakov-Lewis, Philip, and Horton model

\begin{tabular}{|c|c|c|c|c|c|c|c|}
\hline \multirow{2}{*}{ Code } & fo observ & $f c$ observ & \multicolumn{2}{|c|}{ Kostiakov-Lewis model } & \multicolumn{2}{|c|}{ Philip model } & \multirow{2}{*}{$\begin{array}{c}\text { Horton model } \\
\alpha, \min ^{-1} \\
\end{array}$} \\
\hline & \multicolumn{2}{|c|}{$\mathrm{mm} \cdot \mathrm{min}^{-1}$} & $a$ & $b$ & $S, \mathrm{~mm} \cdot \min ^{-0.5}$ & $A, \mathrm{~mm} \cdot \mathrm{min}^{-1}$ & \\
\hline AP1-PMK & 2.17 & 0.33 & 4.89 & 0.94 & 3.34 & 0.04 & 0.25 \\
\hline AP1-KBN & 15.00 & 8.00 & 15.67 & 0.82 & 17.56 & 7.16 & 0.08 \\
\hline AP1-SWH & 0.67 & 0.07 & 2.77 & 1.54 & 0.88 & 0.00 & 0.22 \\
\hline AP2-PMK & 6.17 & 1.50 & 6.85 & 0.93 & 7.84 & 0.94 & 0.09 \\
\hline AP2-KBN & 0.33 & 0.17 & 0.28 & 0.28 & 0.69 & 0.17 & 0.03 \\
\hline AP3-PMK & 9.33 & 5.33 & 4.95 & 0.56 & 7.62 & 5.24 & 0.10 \\
\hline AP3-KBN & 2.00 & 0.67 & 1.76 & 0.50 & 2.77 & 0.55 & 0.06 \\
\hline AP3-SWH & 4.00 & 0.67 & 7.87 & 0.78 & 8.38 & 0.30 & 0.06 \\
\hline AP4-PMK & 1.67 & 0.67 & 1.82 & 0.63 & 2.75 & 0.46 & 0.09 \\
\hline AP4-KBN & 1.33 & 0.33 & 2.07 & 0.82 & 2.18 & 0.16 & 0.11 \\
\hline AP5-PMK & 6.33 & 2.33 & 4.90 & 0.65 & 7.56 & 1.89 & 0.14 \\
\hline AP5-KBN & 11.67 & 5.00 & 10.93 & 0.70 & 12.68 & 4.81 & 0.07 \\
\hline AP5-HTN & 16.00 & 5.00 & 11.03 & 0.49 & 17.42 & 5.49 & 0.18 \\
\hline
\end{tabular}

Explanations: $f o$ observ $=$ observed initial infiltration rate $\left(\mathrm{mm} \cdot \mathrm{min}^{-1}\right), f c$ observ $=$ observed final infiltration rate $\left(\mathrm{mm} \cdot \mathrm{min}^{-1}\right), a, b=$ the empirical parameters, $S=$ sorptivity $\left(\mathrm{mm} \cdot \mathrm{min}^{-0.5}\right), A=$ saturated hydraulic conductivity $\left(\mathrm{mm} \cdot \mathrm{min}^{-1}\right), \alpha=$ constant of the infiltration rate $\left(\mathrm{min}^{-1}\right)$. Source: own study.

the value of $K$ is quite similar with the research results of ASKARI et al. [2008] and OLORUNFEMI [2011].

Regarding the Kostiakov and Kostiakov-Lewis model, the parameter value of " $b$ " is inversely proportional to the initial infiltration rate $(f o)$, whereas the value of " $a$ " is directly proportional to the initial infiltration rate $(f o)$. Since the value of $a$ approached the initial infiltration rate $(f o)$, it can be concluded that the value of $a$ is correlated with the capillary force at the beginning of infiltration. The value of sorptivity $(S)$ in the Philip model was close to the value of the initial infiltration rate $(f o)$. This is due to the function of $S$ parameter which has the soil suction potential. In the Horton model the value of $\alpha$ is directly proportional to the initial infiltration rate $(f o)$; the higher the $\alpha$, the higher the initial infiltration rate.

\section{COMPARISON BETWEEN THE OBSERVED FIELD DATA AND THE INFILTRATION MODELS}

The results of hypothesis testing using the chi-square test at 5\% of confidence level indicated that there is no significant difference between the observed infiltration rate and the results obtained from different infiltration models. The highest infiltration rate was in the forest, while the lowest was in the rice field (see

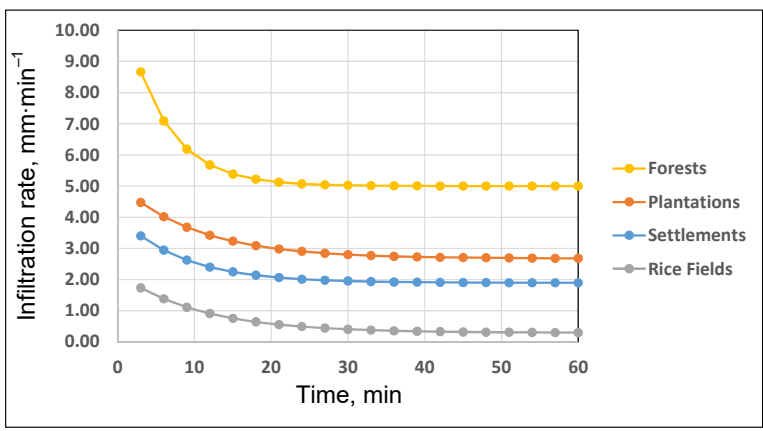

Fig. 2. Infiltration rate in different land uses; source: own study
Fig. 1). Figure 2 shows the average of direct measurement infiltration values from each land use type.

The figure shown that the smallest infiltration on rice fields. This low value was caused by high soil moisture as rice fields require high amount of water. The highest of soil moisture has an impact on the infiltration rate [HAGJNAZARI et al. 2015] even though the soil has a low bulk density and high porosity.

\section{EVALUATION OF THE PERFORMANCE OF THE INFILTRATION MODELS}

The performance of each infiltration model was evaluated based on the value of RMSE, NSE, and $r^{2}$. The results of evaluation, as presented in Table 7, suggest that Kostiakov is the best performing model, followed by Kostiakov-Lewis, Horton, Philip and Green-Ampt model.

Table 7. Performance score of each infiltration model

\begin{tabular}{|l|c|c|c|}
\hline \multirow{2}{*}{\multicolumn{1}{|c|}{ Infiltration model }} & \multicolumn{3}{|c|}{ Performance score } \\
\cline { 2 - 4 } & $R M S E$ & $N S E$ & $r^{2}$ \\
\hline Green-Ampt model & 0.53 & 0.50 & 0.76 \\
\hline Kostiakov model & 0.46 & 0.69 & 0.75 \\
\hline Kostiakov-Lewis model & 0.48 & 0.65 & 0.80 \\
\hline Philip model & 0.57 & 0.57 & 0.76 \\
\hline Horton model & 0.55 & 0.64 & 0.77 \\
\hline
\end{tabular}

Explanations: RMSE, NSE, $r^{2}$ as in Tab. 1.

Source: own study.

Table 8. The most suitable infiltration model for each different land use

\begin{tabular}{|l|l|c|c|c|}
\hline \multirow{2}{*}{ Land use } & \multirow{2}{*}{ Suitable model } & \multicolumn{3}{|c|}{ Performance score } \\
\cline { 3 - 5 } & & $R M S E$ & NSE & $r^{2}$ \\
\hline Settlements & Kostiakov model & 0.42 & 0.68 & 0.73 \\
\hline Plantation & Kostiakov model & 0.35 & 0.73 & 0.75 \\
\hline Rice field & Kostiakov-Lewis model & 0.14 & 0.91 & 0.94 \\
\hline Forest & Green-Ampt model & 1.89 & 0.49 & 0.52 \\
\hline
\end{tabular}

Explanations: RMSE, NSE, $r^{2}$ as in Tab. 1.

Source: own study. 
Table 9. Infiltration model for each different soil texture

\begin{tabular}{|c|c|c|c|c|c|c|c|c|c|c|c|c|c|c|c|}
\hline \multirow[t]{2}{*}{ Soil texture } & \multicolumn{3}{|c|}{$\begin{array}{l}\text { Green-Ampt } \\
\text { model }\end{array}$} & \multicolumn{3}{|c|}{$\begin{array}{l}\text { Kostiakov } \\
\text { model }\end{array}$} & \multicolumn{3}{|c|}{$\begin{array}{c}\text { Kostiakov-Lewis } \\
\text { model }\end{array}$} & \multicolumn{3}{|c|}{$\begin{array}{l}\text { Philip } \\
\text { model }\end{array}$} & \multicolumn{3}{|c|}{$\begin{array}{c}\text { Horton } \\
\text { model }\end{array}$} \\
\hline & $R M S E$ & NSE & $r^{2}$ & $R M S E$ & $N S E$ & $r^{2}$ & $R M S E$ & $N S E$ & $r^{2}$ & $R M S E$ & $N S E$ & $r^{2}$ & $R M S E$ & $N S E$ & $r^{2}$ \\
\hline Silty loam & 0.48 & 0.41 & 0.74 & 0.46 & 0.56 & 0.74 & 0.43 & 0.66 & 0.75 & 0.39 & 0.68 & 0.73 & 0.39 & 0.60 & 0.80 \\
\hline Sandy loam & 1.08 & 0.63 & 0.72 & 1.25 & 0.54 & 0.72 & 1.31 & 0.52 & 0.69 & 1.06 & 0.67 & 0.68 & 1.12 & 0.63 & 0.72 \\
\hline Loam & 0.17 & 0.47 & 0.79 & 0.16 & 0.55 & 0.80 & 0.14 & 0.69 & 0.80 & 0.13 & 0.68 & 0.79 & 0.14 & 0.71 & 0.87 \\
\hline Silty clay & 0.38 & 0.79 & 0.95 & 0.40 & 0.75 & 0.95 & 0.31 & 0.86 & 0.95 & 0.19 & 0.95 & 0.95 & 0.25 & 0.90 & 0.94 \\
\hline
\end{tabular}

Explanations: RMSE, NSE, $r^{2}$ as in Tab. 1.

Source: own study.

Results in Table 8 reveal that the Kostiakov model is suitable for settlements and plantations. Moreover, the Kostiakov-Lewis model is reported as the most suitable method for the rice fields, while GreenAmpt model is more applicable for forest land.

In addition, the suitability of the model on various soil textures is presented in Table 9 in which based on model performance test results, the Kostiakov model showed as the most applicable method for a wide range of soil texture.

\section{CONCLUSIONS AND SUGGESTIONS}

The results of this study have led us to conclude that Kostiakov model, compared to Kostiakov-Lewis, Green-Ampt, Philip, and Horton, is the most suitable for mineral soils with rapid infiltration rate (the final infiltration rate $\left(f_{c}\right)$ bigger than $0.42 \mathrm{~mm} \mathrm{~min}^{-1}$ ). This is in contrast with the results of MBAGWU [1993], showing that that modified models of Kostiakov and Philip were more suitable.

The findings of the present study also indicate that the infiltration rate is influenced by a number of factors such as bulk density, porosity, soil moisture, and soil texture; this is in good agreement with HAGHNAZARI et al. [2015]. Moreover, the infiltration model parameters correlate closely with the initial infiltration rate $(f o)$ and the final infiltration rate $(f c)$. In other words, there is a correlation between the soil's ability to absorb water (representing the capillary force or horizontal flow) at the beginning of the infiltration $(f o)$ and the gravity or the vertical flow upon reaching the final infiltration rate $(f c)$.

As suggestion, taking into account the drawback of the Kostiakov model, namely the tendency of infiltration rate to approach zero at long elapsed times, it is recommended to use Kostiakov-Lewis or Horton model that adding final infiltration rate parameter $\left(f_{c}\right)$; as shown in this study, these two also showed a fairly good performance and were the next best models after the Kostiakov model.

\section{REFERENCES}

Abdulkadir A., Wuddivira M.N., Abdu N., Mudiare O.J. 2011. Use of Horton infiltration model in estimating infiltration characteristics of an alfisol in the Northern Guinea Savanna of Nigeria. Journal of Agricultural Science and Technology. A 1 p. 925-931.

Aghasi B., Jalalian A., Honarjoo N. 2010. The comparison of some soil quality indexes in different land use of
Ghareh Aghaj watershed of Semirom. Isfahan. Iran. International Journal of Environmental and Earth Science. Vol. 1. No. 2. p. 76-80.

ASDAK C. 2002. Hidrologi dan pengelolaan daerah aliran sungai [Hydrology and watershed management]. Yogyakarta. Gadjah Mada University. ISBN 979-420737-3 pp. 618.

Askari M., TANaka T., Setiawan B.I., Saptomo S.K. 2008. Infiltration characteristics of tropical soil based on water retention data. Journal of Japan Society of Hydrology and Water Resources. Vol. 21. No. 3 p. 215227.

BMKG 2016. Peta klasifikasi tipe iklim Schmidt Ferguson dan Oldeman (data tahun 1981-2010) di Propinsi Jawa Timur [Climate map of Schmidt Ferguson and Oldeman (data from 1981-2010) in East Java Province] (Map). Malang. Badan Meteorologi, Klimatologi dan Geofisika.

Brakensiek D., Onstad C. 2000. Parameter estimation of the Green Ampt infiltration equation. Water Resources. Vol. 13. No. 6 p. 1009-1012.

Bresler E., Dagan G., Wagenet R., Laufer A. 1984. Statistical analysis of salinity and texture effects on spatial variability of soil hydraulic conductivity. Soil Science Society of America Journal. Vol. 48(1) p. 16-25.

CZYŻYK F., ŚWIERKOT Z. 2017. Recharging infiltration of precipitation water through the light soil, in the absence of surface runoff. Journal of Water and Land Development. No. 32 p. 25-30. DOI 10.1515/jwld-2017-0003.

DeC D., JosÉ D., FAZEKAS O., HoRN R. 2008. Effect of bulk density on hydraulic properties. Journal of Soil Science and Plant Nutrition. Vol. 8(1) p. 1-13.

FulazZaKy M., Yusop Z., IbRAhim I., Kassim A. 2014. A new technique using the aero-infiltrometer to characterise the natural soils based on the measurements of infiltration rate and soil moisture content. Hydrology and Earth System Sciences. Vol. 11 p. 2515-2553.

GreEN W., AmPT H. 1911. The flow of air and water through soils. Agricultural Sciences.Vol. 4 p. 1-24.

HADISUSANTO N. 2011. Aplikasi hidrologi [Applied hydrology]. Malang. Jogja Mediautama. ISBN 978-602-913603-6 pp. 294.

HaghnaZari F., Shahgholi H., Feizi M. 2015. Factors affecting the infiltration of agricultural soils. International Journal of Agronomy and Agricultural Research. Vol. 6. No. 5 p. 21-35.

HARDJOWIGENO S. 2002. Ilmu tanah [Soil science]. Jakarta. Akademika Presindo. ISBN 978-602-8402-30-9.

HORTON R. 1940. An approach toward a physical interpretation of infiltration capacity. Soil Science Society of America Journal. Vol. 5 p. 339-417.

Kostiakov A. 1932. O dinamike koefficienta prosachivania vody $\mathrm{v}$ pochvogrunty $\mathrm{i}$ neobkhodimosti dinamicheskogo podkhoda $\mathrm{k}$ ego izucheniu $\mathrm{v}$ meliorativnykh celyakh [On the dynamics of the coefficient of water- 
-percolation in soils and on the necessity of studying it from a dynamic point of view for purposes of amelioration]. Pochvovedenie. No 3 p. 293-298.

Krause P., Boyle D., BASE F. 2005. Comparison of different efficiency criteria for hydrological model. Advances in Geosciences. Vol. 5 p. 89-97.

Lemeshow S., Hosmer Jr D.W., Klar J., Lwamga S.K. 1990. Adequacy of sample size in health studies. Chichester. John Wiley \& Sons. ISBN 0-471-92517-9 pp. 239.

Li Z., LIU W.Z., ZHANG X.C., ZHENG F.L. 2009. Impacts of land use change and climate variability on hydrology in an agricultural catchment on the loess plateau of China. Journal of Hydrology. Vol. 377 p. 25-42.

MbagWU J. 1993. Testing the goodness of fit of selected infiltration. Trieste. International Centre for Theoretical Physics pp. 17.

NASH J.E., Sutcliffe J.V. 1970. River flow forecasting through conceptual models. Part I. A discussion of principles. Journal of Hydrology. Vol. 10. p. 282-290.

OLORUNFEMI I., FASINMIRIN J. 2011. Hydraulic conductivity and infiltration of soils of tropical rain forest climate of Nigeria. Abeokuta. Federal University of Agriculture p. $397-413$

ORUK E. 2011. Infiltration rate assessment of coastal plain (ultisol) soils for sustainable crop production in the frontiers of Calabar - Nigeria. Journal of Sustainable Development. Vol. 4 p. 222-229.

Peel M., Finlayson B., McMahon T. 2007. Updated world map of Köppen-Geiger climate classification. Hydrology and Earth System Sciences. Iss. 11 p. 16331644.

PHILIP J. 1957. The theory of infiltration: 1. The infiltration. Soil Sciences. Vol. 83 p. 345-357.

PRIJONO S., MidiYANINGRUM R., NAFRIESA S. 2015. Infiltration and evaporation rate in different landuse in the Bango Watershed. Malang District. Indonesia. International Journal of Agriculture and Research. Vol. 3. Iss. 4 p. 1061-1067.
Rawls W.J., Brakensiek D., Miller N. 1983. GreenAmpt infiltration parameters from soils data. Journal of the Hydraulic Division - American Society of Civil Engineers. Vol. 109(1) p. 62-70.

RiCHARDS L.A. 1931. Capillary conduction of liquids through porous materials. Physics. No. 1 p. 318-333.

RosCOE J.T. 1975. Fundamental research statistics for the behavioural sciences. $2^{\text {nd }}$ ed. New York. Holt Rinehart \& Winston pp. 483.

SChIPPER L., Sparling G. 2000. Performance of soil condition indicators across taxonomic groups and land uses. Soil Science Society of America Journal. Vol. 64 p. $300-311$

Silva M., Netto A., Neves R., Vasco A., Almeida C., FACCIOLI G. 2015. Sensitivity analysis and calibration of hydrological modeling of the watershed Northeast Brazil. Journal of Environmental Protection. Iss. 6 p. $837-850$.

Subardja D., Ritung S., Anda M., Sukarman S., SubanDIONO R.E. 2014. Petunjuk teknis klasifikasi tanah nasional [Technical guidelines of land classification in Indonesia]. Bogor. Balai Besar Penelitian dan Pengembangan Sumberdaya Lahan Pertanian. Badan Penelitian dan Pengembangan Pertanian. ISBN 978-602-8977-85-2 pp. 45.

SUBRAMANYA K. 2013. Engineering hydrology. New Delhi. Mc Graw Hill Education. ISBN 1259029972 pp. 534.

Thornleya J., CANNEll M. 2010. Managing forest for wood yield and carbon storage: A theoretical study. Tree Physiology. Vol. 20 p. 477-484.

USDA, NRCS 2010 . Keys to soil taxonomy. $11^{\text {th }}$ ed. Washington. United States Department of Agriculture \& Natural Resources Conservation Service pp. 338.

VAGHeFi M., Rahideh H. 2011. Description of the G-A infiltration model using $\mathrm{Chu}$ and Chow viewpoints. Journal of Applied Sciences and Environmental Management. Vol. 15. No. 1 p. 31-36.

Walker W., Skogerboe G. 1987. Surface irrigation: theory and practice. Englewood Cliffs. Prentice-Hall. ISBN 0138779295 pp. 386.

\section{Nugroho SURYOPUTRO, SUHARDJONO, Widandi SOETOPO, Ery S. SUHARTANTO, Lily M. LIMANTARA}

Ocena modeli infiltracji opracowanych dla gleb mineralnych o różnym typie użytkowania w tropikach

\section{STRESZCZENIE}

Celem badań prezentowanych w niniejszej pracy była ocena pięciu modeli infiltracji opracowanych dla gleb mineralnych o różnym typie użytkowania $\mathrm{w}$ tropikach, takich jak: obszary zabudowane, plantacje, pola ryżowe i lasy. Oceniano modele Greena-Ampta, Kostiakova, Kostiakova-Lewisa, Philipa i Hortona. Badania prowadzono w zlewni Amprong, Malang w Indonezji. Analizowano tempo infiltracji w trzynastu próbkach glebowych $\mathrm{z}$ użyciem infiltrometru Turf-Tech. Ponadto w każdej próbce gleby analizowano gęstość objętościową, ciężar właściwy, porowatość, wilgotność gleby i skład granulometryczny. Wyniki badań dowiodły, że nie ma istotnej różnicy w tempie infiltracji $(\alpha=5 \%$ ) obliczonej za pomocą wymienionych pięciu modeli. Uznano, że tempo infiltracji było duże. Trzy modele, kolejno: Kostiakova, Kostiakova-Lewisa i Hortona okazały się najbardziej odpowiednie. Największe tempo infiltracji stwierdzono w glebach leśnych, a najmniejsze w glebach pod polami ryżowymi. Wyniki badań sugerują, że parametry modelu infiltracji są ściśle skorelowane z początkowym $(f o)$ i końcowym $(f c)$ tempem infiltracji. Innymi słowy, istnieje korelacja między zdolnością gleby do absorbowania wody (reprezentowana przez siły kapilarne i przepływ poziomy) na początku infiltracji (fo) oraz siłą ciążenia i przepływem pionowym po osiągnięciu końcowego tempa infiltracji $(f c)$.

Słowa kluczowe: gleby mineralne, klimat tropikalny, modele infiltracji, użytkowanie ziemi 